\title{
ANXIETY AND COMPETENCE ACHIEVEMENT OF MIDWIFERY STUDENTS DURING MIDWIFERY CLINICAL PRACTICE OF MATERNAL NEONATAL EMERGENCY
}

\author{
Anis Kusumawati*, Titi Savitri Prihatiningsih**, Yayi Suryo Prabandari** \\ * Faculty of Medicine, Purwokerto Muhammadiyah University, Purwokerto - INDONESIA \\ ** Faculty of Medicine, Universitas Gadjah Mada, Yogyakarta - INDONESIA
}

\begin{abstract}
Background: Anxiety is often experienced by students when following clinical education. Anxiety at moderate level is required for the learning process, but at high level it lowers the learning. The objective is to determine the level of anxiety, competency achievement, the relationship between them and the things that are perceived by the students and the clinical instructors when following clinical practice.

Methods: A quantitative, cross sectional study using questionnaires to 42 midwifery students continued with the qualitative by in-depth interviews with three students and six clinical instructors.

Results: The level of anxiety was no to mild anxiety by $19.05 \%$, mild to moderate anxiety by $66.67 \%$, and moderate to severe anxiety by $14.28 \%$. Around $2.38 \%$ of the students earned a grade of a B, $45.24 \%$ earned a B + and $52.38 \%$ earned an A. The relationship between the level of anxiety and competency achievement was shown with an $r$ value of -0.043 .

Conclusion: The level of anxiety in clinical practice of midwifery students was mild to moderate, and the competency achievement was excelent. There was a negative and very weak correlation between the level of anxiety and competency achievement. Things perceived by the student following clinical practice were a matter of personalization, innovation, individualization, involvement, task orientation, and satisfaction, while things perceived by the clinical instructors were a matter of time constraints, much work load, student preparedness, student ability level, challenge to patient, student motivation, and hospital environments.
\end{abstract}

Keywords: anxiety, competency achievement, clinical practice

\section{ABSTRAK}

Latar belakang: Kecemasan sering dialami mahasiswa ketika mengikuti pendidikan klinik. Kecemasan pada tingkat yang sedang dibutuhkan untuk proses pembelajaran namun pada tingkat yang tinggi menurunkan pembelajaran. Tujuan penelitian untuk mengetahui tingkat kecemasan, pencapaian kompetensi, dan hubungan di antaranya serta menggali hal-hal yang dirasakan oleh mahasiswa dan pembimbing klinik ketika mengikuti praktik klinik.

Metode: Kuantitatif, cross-sectional dengan menggunakan kuesioner pada 42 mahasiswa kebidanan dilanjutkan kualitatif dengan menggunakan wawancara terhadap 3 mahasiswa dan 6 pembimbing klinik.

Hasil: Tingkat kecemasan tidak cemas sampai ringan 19,05\%, ringan sampai sedang 66,67\%, sedang sampai berat 14,28\%. Pencapaian kompetensi nilai B sebanyak 2,38\%, B 45,24\% dan A 52,38\%. Hubungan antara tingkat kecemasan dan pencapaian kompetensi $r=-0,043$

Kesimpulan: Dalam praktik klinik tingkat kecemasan mahasiswa kebidanan sebagian besar adalah cemas ringan sampai sedang dan pencapaian kompetensi istimewa. Terdapat hubungan negatif deng an kekuatan sangat lemah antara tingkat kecemasan dan pencapaian kompetensi. Hal-hal yang dirasakan mahasiswa ketika praktik klinik adalah masalah

contact: dokteranis@yahoo.co.id 
personalisasi, inovasi, individualisasi, keterlibatan, orientasi tugas, rasa puas dan penilaian. Hal-hal yang dirasakan oleh pembimbing klinik adalah masalah keterbatasan waktu, tugas yang banyak, kesiapan mahasiswa, tingkat kemampuan mahasiswa, tantangan pada pasien, motivasi mahasiswa, dan lingkungan rumah sakit.

Kata kunci: kecemasan, pencapaian kompetensi, praktik klinik

\section{INTRODUCTION}

Anxiety is a normal response towards a threatening situation and may be able to motivate positive things, including during an exercise or studying. ${ }^{1}$ Anxiety may become a problem when it interferes with normal functions, is not related to a real threat, develops physical symptoms, and is not tolerated by the person. ${ }^{1}$ Anxiety is a synonym to stress, at moderate level it is needed for learning process, but at high level it reduces learning. ${ }^{2}$ Anxiety affects academic achievement greatly. There is a negative relationship between anxiety and academic achievement, where higher anxiety decreases academic achievement. ${ }^{3}$ In clinical education, high anxiety reduces the quality of clinical experience. ${ }^{4}$ Anxiety causes lack of attention, memory, and concentration control, so it lower academic performance. ${ }^{3}$ Anxiety also decreases students' problem-solving ability. ${ }^{4}$

Anxiety is often seen in students in clinical education with higher occurrence compared to anxiety in class environment. ${ }^{2,4}$ A study by Carvalho et al. (2014) showed that $80 \%$ of nursery students suffered from moderate anxiety during clinical education. ${ }^{5}$

Clinical practice education is a big part of learning process in 3-year midwifery diploma program as a vocational education with $60 \%$ practical learning and $40 \%$ theoretical learning. ${ }^{6}$ Subjects distribution in this study program puts maternal neonatal emergency in the fifth semester (third year). ${ }^{7}$ This particular clinical practice educates students to reach the competence to handle maternal and neonatal emergency, including assessment, diagnosis, planning development, implementation, evaluation, and documentation. ${ }^{8}$

Unstructured interviews with a few third-year midwifery students obtained the information that clinical practice, especially midwifery clinical practice of maternal neonatal emergency, generated anxiety/ stress to students. Anxiety is a major obstacle of clinical learning causing students unable to work well. ${ }^{2}$

According to the description above, a study is needed to know the anxiety level, competence achievement, and the relationship between anxiety level and competence achievement, as well as to explore what students and clinical counselors feel during midwifery clinical practice of maternal neonatal emergency.

\section{METHODS}

This study used quantitative and qualitative methods. Cross-sectional quantitative study used a questionnaire to 42 midwifery students taking clinical practice education. Qualitative study was done to obtain the characteristics of the students and anxiety level data.

A questionnaire adopted from a questionnaire by Emilia (2003) was used to measure students' anxiety level. ${ }^{9}$ Several items in that questionnaire were revised to be adjusted to midwifery student clinical skills learning. The questionnaire consisted of 20 items, with 4 response choices using Likert scale. The range were 0 (no anxiety), 1 (mild anxiety), 2 (moderate anxiety), and 3 (severe anxiety). Mean anxiety score was sorted into 7 groups: mean score of 0 meant no anxiety, mean score of 0 to 1 meant no anxiety to mild anxiety level, mean score of 1 to 2 meant mild to moderate anxiety level, mean score of 2 meant moderate anxiety level, mean score of 2 to 3 meant moderate to severe anxiety level, and mean score of 3 meant severe anxiety level.

Students' competence achievement data was obtained from grades in midwifery academic. The assessment included clinical performance (70\% of grades) and portfolio (30\% of grades). Assessment was done by 
1 clinical counselor from the hospital and 1 teacher from the program. Both grades were then added and conversed to be $\mathrm{A}$ ( 80 and above), $\mathrm{B}^{+}$(75 to less than $80), \mathrm{B}(70$ to less than 75$), \mathrm{C}^{+}$(60 to less than 70$)$, $\mathrm{C}$ (50 to less than 60$), \mathrm{D}$ (25 to less than 50 ), and $\mathrm{E}$ (less than 25). ${ }^{7}$

Following was qualitative study using in-depth interviews to 2 students with the highest anxiety level with their 3 clinical counselors and 1 student with the lowest anxiety level with her 3 clinical counselors. Indepth interviews were used to explore what students felt during clinical practice.

Quantitative data results analyses used univariate and bivariate test. Univariate test was used to obtain total score, mean score, minimum score, maximum score, and standard deviation data. Bivariate test was used to assess the relationship between anxiety level and competence achievement by using Spearman's correlation. Qualitative data analysis was performed by determining categories and themes.

\section{RESULTS AND DISCUSSION}

Results showed that mean anxiety score of students taking midwifery clinical practice of maternal neonatal emergency was $29.00 \pm 9.04$, far from maximum anxiety score of 60 and under the median of 30. The highest score was 47 (2 students) and the lowest was 8 ( 1 student). 8 students fell in the category of no anxiety to mild anxiety level (19.05\%), 28 students fell in the category of mild to moderate anxiety level (66.67\%), and 6 students fell in the category of moderate to severe anxiety level (14.28\%). Anxiety score data was distributed normally, with $p>$ 0.05 was obtained form Saphiro-Wilk data normality test.

The mean score of midwifery clinical practice of maternal neonatal emergency from 42 students was $80.10 \pm 2.38$. This mean score showed that on average, students had grade A. The lowest midwifery clinical practice of maternal neonatal emergency score was 73.00 with the highest score of 85 . According to this value, all students passed, with 22 students had grade A (52.4\%), 19 students had grade $\mathrm{B}^{+}(45.24 \%)$, and 1 students had grade B (2.38\%). Competence achievement (score) data normality was tested using
Saphiro-Wilk test, with $p<0.05$ that meant the data was not normally distributed.

These results showed that most of the students' anxiety level was under the category of mild to moderate anxiety and the competence achievement was outstanding (Table 1). Statistical analysis results showed low-power negative correlation between anxiety level and clinical skills competence achievement $(r=0.043)$.

These results demonstrated that mean anxiety score was $29.00 \pm 9.04$, in line with a study by Emilia (2003) that found the mean score of the anxiety level in medical students taking clinical practice was $23.46 \pm 1.39$, generally the anxiety level was mild to moderate. ${ }^{9}$ Different results were found by Carvahlo et al. (2004) who demonstrated that $80 \%$ of nursery students had moderate anxiety level during clinical practice. ${ }^{5}$ A study by Tichy and Means (1980) found that $88 \%$ of nursing students had severe anxiety level during their education. The number of students having severe anxiety in clinical education was higher compared to in class or in the lab. ${ }^{2}$ The incidence of anxiety was different. For several students, the incidence of anxiety was related to assessment and then the pressure from clinical education. ${ }^{2}$ Anxiety level also rose accordingly with higher level of education and a few students had the most severe anxiety in their last semester. ${ }^{2}$

From the statistical analysis, it was found that there was a low-power negative relationship between students' anxiety level and competence achievement. It could be understood that higher anxiety level caused lower competence achievement. This is in accordance with the results reported by Cheung \& Au (2011) that with higher anxiety level, students' competence achievement was lower. Different results were reported by Eka (2012) and Amir (2014) that there was no significant relationship between anxiety level and the competence to perform medical action or clinical skills assessment. ${ }^{11,12}$

Some students cannot perform a skill or perform a skill incompletely when they are anxious. Anxious students feel panicky when they are not able to perform difficult tasks it causes them to not be able to concentrate, hence the memory disturbance, 
causing memory deficit. ${ }^{2}$ A study by Fisher (1996) and Yarkes \& Dodson (1998) cited by Melincavage (2008) mentioned that moderate anxiety level improved performance, that easy tasks were more efficiently performed with higher anxiety level, and difficult tasks were more efficiently performed with lower anxiety level. ${ }^{2}$ Moderate anxiety level improved performance, while high anxiety level diminished it. ${ }^{2}$

There are several causes of students' anxiety during clinical practice, mainly are interpersonal relationship and due to performance in clinical practice environment. ${ }^{2}$ From this study, it was known that $40.05 \%$ of the students stated that conflicts against midwives or paramedics were a great cause of anxiety. This is similar with what Al Kadri et al. (2010) stated where his qualitative study mentioned that students indicated that clinical counselors were a potential cause of stress and anxiety. ${ }^{13}$ This was because clinical counselors overestimated their clinical skills, gave out questions, or asked them to perform an action according to the learning objectives in the curriculum, even more so in front of patients or colleagues. ${ }^{13}$ Likewise, Melincavage (2008) also demonstrated that the first category of the sources of stress in clinical education was interpersonal relationship, especially between students and their clinical counselors. ${ }^{2}$ There were a few reasons why a relationship between students and clinical counselors was stressful. Some students claimed that that clinical counselors were not supportive, criticized too much, and made students feel incompetent to care for the patients. ${ }^{2} \mathrm{~A}$ few students felt pressure due to negative feedbacks from clinical counselors and clinical counselors were often not available to meet. Another source of stress was because clinical counselors watched them and evaluated them during clinical education. ${ }^{2}$

From the interviews with the students, it was known that students felt the little opportunities they had to interact with clinical counselors and clinical counselors did not give enough attention to students (personalization). Personalization is giving opportunities to students individually to interact with clinical counselors and clinical counselors give attention to the students. ${ }^{14} \mathrm{~A}$ quantitative and qualitative study by Chan (2001) found that personalization was an important domain in a clinical learning environment, the relationship between students and clinical counselors was an important part in clinical learning process. ${ }^{14} \mathrm{Clinical}$ counselors had the power to influence clinical learning environment, so they had a direct impact to students' learning. Participants' interpersonal relationship in clinical learning environment was crucial in developing good learning environment. ${ }^{14}$ Clinical counselors had the role to make the students able to learn efficiently and effectively through actions. ${ }^{15}$ Students were expected to be supported, respected, and appreciated by their counselors. ${ }^{15}$

Students expressed that they were not guided according to their capability or their interests (individualization). Individualization is when students are permitted to make decisions and guided differently according to their own capability or interests. ${ }^{15}$ The results of this study is similar with the results by Chan (2001) where students expected a learning environment that paid attention to students individually allowing them to participate. ${ }^{14}$

Students expressed their opinions about how they actively participated and were attentive (innovation). Innovation is how clinical counselors plan clinical experiences, teaching techniques, learning activities, and allocation for new, interesting, and productive patients. ${ }^{14}$ Several students felt that clinical counselors were less innovative, especially when there were only a few patients, causing the absence of counseling. Clinical teaching innovation in learning strategies affect students' satisfaction greatly in clinical placing. ${ }^{14}$ Students felt that the task orientation was not clear. Task orientation is how far clinical practice activities are organized clearly and well. ${ }^{14}$ Clear and good task orientation affect the results of clinical practice. $^{14}$

Students expressed their satisfaction in taking clinical practice. Students' satisfaction is how students enjoy their clinical practice. ${ }^{16}$ Students expressed their dissatisfaction in taking clinical practice, they felt they could not endure to be there and did not get the learning they expected, although some students felt the opposite, where they felt at home and happy. Students' satisfaction in clinical practice increased when they were guided well according to their capability and were involved in task execution. ${ }^{14}$ The 
rise of students' satisfaction in clinical practice was related to individualization and task orientation. On the contrary, students were disappointed with uncomfortable clinical environment. Generally, students expected comfortable environment that gave them opportunities to be involved in clinical activities. ${ }^{14}$ Although there was a difference between the reality and students' expectation about clinical activities, there is no proof and it cannot be predicted that individual students' achievement may be improved by transferring them to the environment they expected. ${ }^{15}$ Students' achievement may be improved by trying to change clinical learning environment to be similar with the environment the students expected. ${ }^{14}$

Education in clinical environment is defined as focused education and learning and usually involving patients and their problems directly. ${ }^{17}$ Clinical environment include hospitalized patients, outpatients, community settings where each has their own challenges. ${ }^{18}$

Learning in clinical environment has several excellence, i.e. focusing on real problems, students are motivated by real relationship through active participation, and especially if they feel involved in caring for the patients, their confidence and passion increase. ${ }^{17}$ Clinical education is the only setting where clinical counselors give examples of technical and non-technical skills, attitude, and knowledge application. A few skills such as anamnesis and examination, clinical reasoning, planning and decision making, secret keeping, teamwork and leadership can be learned in an integrated manner. ${ }^{17}$ Besides its excellence potential, clinical education are also criticized due to its variability, weak intellectual challenges, and unplanned environment. ${ }^{17}$

From the interviews with clinical counselors, several problems were found. Clinical counselors felt difficult to organize time to work and to guide students. This is in accordance with what Spencer (2003) expressed where limited time was one of the challenges faced by clinical counselors, as well as an increased workload. ${ }^{17}$ Besides their main task as healthcare providers and in structural management, clinical counselors also had to perform their task to guide students. This is in line with what Spencer (2003) suggested where workloads in caring for patients, administration, and research became challenges for clinical counselors. ${ }^{17}$

Different from the education in campus, clinical education is an education in a place with a complex social context, where clinical counselors watching the clients, students, and other healthcare provider needs. ${ }^{14}$ This may cause patients not to be treated well. Clinical counselors also complained of different levels of students there, at the same time there were 3-year midwifery diploma students, 3-year nursery diploma students, bachelor nursery students, nursery profession students, medical profession students, residents, and intern midwives from many institutions at an incomparable number compared to the number of the patients. Different levels of students and challenges in patients are one of the challenges in clinical education. ${ }^{17}$ This is similar with what Sundler et al. (2014) expressed where excessive number of students would disrupt the education itself. ${ }^{19}$ An increased number of students would cause less ideal clinical environment to learn. ${ }^{20}$ Clinical counselors evaluated that students lacked learning motivation. Learning motivation is the main problem in the world of education because it relates with competence achievement. ${ }^{21}$

The results of students' competence achievement in midwifery clinical practice of maternal neonatal emergency was mostly outstanding (52.5\%), the rest were good and very good. ${ }^{8}$ From the assessment of students' competence achievement it was known that the distribution of the score data was not normal. According to students, clinical counselors did not assess them seriously, evaluated carelessly, valued it as just a formality, and did not know their students well. This is similar with what clinical counselors expressed. They said that assessing students was a burden for them because there was no time to evaluate the students, did not know the students well, felt the burden when particular students did not pass even though actually they had not achieved the competence, as well as a difficult evaluation form to fill. Evaluation in midwifery clinical practice of maternal neonatal emergency used several assessment instruments with predetermined portions by the program. ${ }^{8}$ In clinical education, evaluation was not only conducted once, involving watching the 
students during the practice and making a decision about their performance in a particular time interval and at the end of their practice period. ${ }^{22}$ Assessment process during midwifery clinical practice of maternal neonatal emergency was not conducted well, so that students did not feel satisfied. Clinical examination was clearly needed by the students to know what to learn and this supported students' satisfaction. ${ }^{16}$

From the interviews it was known that clinical counselors gave inputs to improve students' readiness to take clinical practice, aside from better learning motivation. The task to write midwifery care was reduced, so that students were more focused to learn skills. The assessment form was simplified. If possible, the schedule of clinical practice was adjusted so that students from different institutions did not attend the clinical practice at the same time because it might cause excessive number of students at one time, but no students at all at other times.

\section{CONCLUSIONS}

In midwifery clinical practice of maternal neonatal emergency, midwifery students' anxiety level was mild to moderate and the competence achievement was outstanding. There was a low-power negative correlation between anxiety level and competence achievement. The existing problems according to students were personalization, individualization, involvement, task orientation, satisfaction, and assessment. The existing problems according to clinical counselors were limited time, many tasks, students' readiness, students' capability level, challenges in patients, students' motivation, and hospital environment.

\section{RECOMMENDATIONS}

Future studies are expected to use more respondents, with standardized learning process and assessment in all clinical practice places, and the measurement of anxiety level is to be done multiple times.

\section{CONTRIBUTIONS}

Kusumawati compiled the study and all authors contributed in the research design. Kusumawati conducted the study and data analysis was performed by all authors. Kusumawati wrote the paper draft and all authors contributed in perfecting the final draft.

\section{ACKNOWLEDGEMENT}

Authors thank dr. E. Suryadi, SU, PA(K), MHPE and dr. Widyandana, MHPE, Ph.D for the suggestions as well as Prof. dr. Ova Emilia, M.Med.Ed, Sp.OG(K), Ph.D for permitting to use her questionnaire in this study.

\section{ETHICAL CLEARANCE}

This study received an ethical clearance from Komisi Etik Kedokteran dan Kesehatan FK UGM with reference number KE/FK/281/EC.

\section{REFERENCES}

1. Lucas MPP. Mental illness nursing documents for nurses and midwives. Queenslad: Queensland Mind essentials; 2010.

2. Melincavage SM. Anxiety in student nurses in the clinical setting: a phenomenological study [dissertation]. Pennsylvania: The Pennsylvania State University; 2008.

3. Nadeem M, Ali A, Maqbool S, Zaidi SU. Impact of Anxiety on the Academic Achievement of Students Having Different Mental Abilities at University level in Bahawalpur (Southern Punjab) Pakistan. IOJES. 2012;4 (3):519-28.

4. Flynn K. The use of standardized patients to minimize anxiety in undergraduate nursing students in the clinical setting [Master of Arts in Nursing Theses]. St. Catherine University; 2012.

5. Carvalho R, Farah OGD, Galdeano LE. Nursing undergraduates' anxiety about the first surgical instrumentation. Rev. Latino-Am. Enfermagem. 2004;12(6).

6. Keputusan Menteri Pendidikan Nasional Republik Indonesia nomor 045/U/2002 tentang kurikulum pendidikan tinggi.

7. Panduan Akademik. Fakultas Ilmu Kesehatan Universitas Muhammadiyah Purwokerto. 2014.

8. Panduan Praktik Klinik Kebidanan Kegawatdaruaratan Maternal Neonatal. Program Studi Diploma III Kebidanan Fakultas Ilmu Kesehatan Universitas Muhammadiyah Purwokerto. 2014. 
9. Emilia O. The Relationship between the clinical learning environment and the approach to learning of medical students [thesis]. New South Wales Medical Education School of Public Health and Community Medicine. The University of New South Wales. 2003.

10. Cheung RY, Au TK. Nursing students' anxiety and clinical performance. J Nur Educ. 2011; 50: 286-9.

11. Eka, A.R. Hubungan antara tingkat kecemasan dennan keberhasilan memberikan obat melalui infus pada mahasiswa FIK UI angkatan 2010. [skripsi]. Jakarta (Indonesia). Universitas Indonesia;2012.

12. Amir, D.P. Hubungan tingkat kecemasan dalam menghadapi Objective Structured Clinical Examination (OSCE) dengan nilai OSCE mahasiswa Fakultas Kedokteran Universitas Andalas [skripsi]. Padang (Indonesia). Universitas Andalas; 2014

13. Al-Kadri HMF, Al-Moamary MS, Elzubair M, Magzoub ME, Al-Mutairi A, Roberts C, Cees van deeeer Vleuten. Exploring factors affecting undergraduate medical students\study strategies in the clinical years: a qualitative study. Health Sci Educ. 2011;16:553-67.

14. Chan DSK. Combining qualitative and quantitative methods in assessing hospital learning environments. Int J Nur Stud. 2001;38:447-59

15. Wing G. Pre-registration student nurses perception of the hospital-learning environment during clinical placement. Nurse Educ Today. 2006;26:338-45.
16. Yim WIP, Chan DSK. Hong Kong nursing student's perception of clinical environment: a qustionanaire survey. IJNSTU. 2005;42:665-672.

17. Spencer J. ABC of learning and teaching in medicine. Learning and teaching in the clinical environment. BMJ. 2003; 326:591-4.

18. Ramani S, Leinster S. Amee guide no. 34: teaching in the clinical environment. Med Teach. 2008;30:34764.

19. Sundler JA, Bjork M, Bisholt B, Ohlsson U, Engstrom AK, Gustafsson M. Student nurses'experiene of the clinical learning environment in relation to the organizastion of supervision: A questionnair survey. Nurs Educ Today 2014.

20. Dent JA. AMEE Guide No 26: clinical teaching in ambulatory care settings: making the most of learning opportunities with outpatients. Med Teach. 2005;27(4):302-15.

21. Ames CA. Motivation: what teachers need to know. Teacher College Record. 1990;91(3):409-21.

22. Hunt LA, McGee P, Gutteridge R, Hughes M. Assessment of student nurses in practice: A comparison of theoretical and practical assessment results in England. Nurse Educ Today. 2011;2-5. 